\title{
Integration and Development of Industrial Organization: The Case Study of Sugar Industry in China
}

\author{
Yaxin WANG \\ Business School, Zhanjiang Normal University, Zhanjiang, China \\ 416699575@qq.com
}

\begin{abstract}
Since China's reform in the economic system and opening to the world, China's sugar industry has been developed rapidly, which has verified the industrial organization theory that in a competitive market structure, industrial organization will expanded gradually, develop an intensive industry concentration and improve its performance. The result from Case study shows that, whether an organization chooses expansion or reduction depends on the resource scarcity rate. And the expansion to control scarce resources is its inner motivation. Uniqueness factors like the local customs, if adopted in the management, can improve the core competence of enterprises and ensure the effectiveness of resource integration. Scale economy must be built on the basis of the scale of economies. According to their own development stage, enterprises may choose to control the whole industry chain or some of the industrial chain links, to gain profits based on the scale or scope of the economies. The Case enterprise has innovated the operating mechanism and developed three patterns, which are mutual benefit, independent operation and contract mode, to achieved the aim of expanding scale, reducing transaction costs, and improving efficiency.
\end{abstract}

KEYWORD: organizationt; marketing structure integration of industrial organization; strategic contingency of organization

\section{INTRODUCTION}

Traditional SCP theory (Structure - Conduct Performance) suggests that structure controls conduct, and conduct determines performance. Noncompetitive companies are expelled through full market competition. In contrast, competitive companies increase industry concentration, achieve good market performance and industry health by reducing costs and expanding the scales. Stateowned enterprises have become diversified in ownership of entities since 1978. Industrial organization, marketing structure and industrial performance have changed while the ownership changes. The evolution of China's industrial organization under the background of high economic growth can deepen the understanding of the law of industrial development, and enrich industrial organization theory.

Cane sugar industry is one of the basic industries which integrates planting, agro-industries and food processing industry. The management of sugar industry is extended to the fields due to its dependence on cane planting. And its quality plays an important role in increasing the income of farmers, agricultural efficiency as well as food safety.
Cane sugar industry is not only in the impact of the marketing price mechanism but also in the impact of cane life activities. The development of technology for sugar industry enlarges its by-products utilization. Elongate its chain, and enriches its forms of industrial organization. Studying sugar industry organization has an important practical value for the progress of the theory of industrial organization, sustainable development of sugar industry, and agriculture and rural development in China, which is decided by the nature of sugar industry and the industrial transformation from a planned system a market system in China.

Literature Review Market structure is the interconnected characteristics of a market, such as the number and relative strength of buyers and sellers and degree of collusion among them, level and forms of competition, extent of product differentiation, and ease of entry into and exit from the market. After E. H. Chamberlin, Joan Robinson proposed theory of monopolistic competition, and four different types of market structure was divided according to the different industrial monopoly and competition, market structure was more specifically divided into different level of more practical competition and monopoly by some other scholars, 
such as Joe S. Bain and Uekusa, Masu. It was thought that the main factors that affect the market structure are market concentration, scale economies, Barriers to entry, and product differentiation.

The quantity of manufacturers and scale of industries are the main factors of market structure. In recent years, the research for the industry organization has changed from the static analysis into the dynamic study. Mindan et al(2008) held that research results indicated that the number of entry would reach a peak with the increase of the market demand in the early period, and then it will decline to a stable level and keep on for a long-term in the middle and later periods. Thus, companies have to adjust its development strategy according to their own market structure and stages of industry development in order to adapt to market changes. Paul. A. Samuelson considered the most powerful factor of organization in the enterprise was the economy of scale production. Traditional cost theory thinks that enterprises will continue to reduce production costs till the suitable scale with the expansion of business scale. If the companies go on expanding the scale, costs would increase owning to uneconomic management. Transaction cost theory gave a unique interpretation for economies of scale from the perspective of market transaction costs. Coase (1960) pointed out that the existence of transaction costs was the root causes of enterprise existence; The enterprise had actually become a substitute for the market. Only when the internal management fees equal to its market transaction cost, would the scale of the business expansion stop. In addition, the transaction cost theory also explained the enterprise integration. Coase argued that when two or more business transactions were done by one company, enterprise integration would appear which actually the process of internalization of transactions is. In other words, every step of the relationship changes in the structure between Businesses was related to economies of scale. The success of mergers between companies depends on the comparison with the increasing organization costs and saving transaction costs. Chandler (1990) studied two modes of growth and competition for modern industry in the developed countries. One was scale competition. "Economies of scale mean increase efficiency of production as the number of goods being produced increases or the cost of production or sale of unit product decreases" (Chandler, 1990). It is called specialization strategy (Porter, 1985). The other model was the scope of competition. Economies of scope refer to the reduction of per-unit costs through the production of a wider variety of goods or services (Chandler, 1990). It is called diversification strategy. Chandler (1977) showed companies used different strategies in their different development stages in order to grow and profit. The growth path of most American companies was from specialization to vertical Integration and then to diversification.

Agricultural product processing industry is production activities using agricultural materials and wildlife resources as raw materials for industrial production. It has its own particularity in addition to general characteristics. Agricultural is the process of economic reproduction and natural reproduction. It has the nature of cyclical process, the dependence of land and natural conditions, as well as easy of injury and putridity. These become a unique constraint, risk and special needs for agricultural products processing industry. The forms of industrial organization are required to adapt it. It may be resorted to integrate vertical or horizontal integration for the industrial chain when industrial organization faced uncertain environment. In these fields, Williamson (1980) underlined the specific using of the assets will generate quasi-rents. Contention for the quasi rents for opportunists would generate transaction costs in uncertainty environment, and industry chain of vertical integration, however, will reduce transaction costs. Mulla Nathan(2001) said although vertical integration can save transaction costs, the integrated part would lose motivation and efficiency for losing residual rights of control, and it also can be seen as the combined costs of integration, there is fewer studies on agricultural products processing industry from the aspect of industrial organization. The research of agricultural products of industrial organization in China is also relatively weak, and it mainly focus on the problems about "Agriculture, Rural areas and Farmers" ("San Nong" problems). And few related researches are scattered in individual industrial organization.

\section{DATA SOURCES AND OVERVIEW OF SUGAR INDUSTRY IN CHINA}

\subsection{Data sources}

The data mainly came from the Chinese statistical yearbook for each year, China Sugar Association Annual Report, annals of sugar cane crop provinces, and Guangxi Sugar Network and related information on corporate websites. Meanwhile, by interviewing the sugar cane farmers and sugar mills in relevant sugar county, we have collected some firsthand additional information.

\subsection{Overview of sugar industry in China}

Modern sugar industry appeared in the 30's of last century, but it developed poorly because of years of war. In 1949, there were only two sugar cane factories whose production was less than 1,000 tons per day. After the founding of the People's Republic of China, a complete sugar system was gradually built up from sugar cane production, sugar cane 
processing and sale of sugar. After the implementation of reform and the opening of doors to the international community, the government timely adjusted the layout of the regional sugar industry according to economic law and natural conditions. Zhanjiang of Guangdong, Guangxi, Yunnan, Xinjiang and other sugar-producing region become the bases of sugar production after a series of adjustments of westward movement and southward movement. The Sugar production of these areas amounts to more than $70 \%$ of total national output. In 1991, China achieved self-sufficiency in sugar, on a low level though. From 1991 to1992, it amounted to 7.916 million tons in the whole country, making China the third largest sugar-producing countries in the world. In 1992, China began to export sugar to participate in the competition in the international market. In 2013, it amounted to 1306.84 million tons. The data in Table 1 compares the basic situation of China's sugar industry in 2010 and 1949.

TABLE1: ChinA’s SUGAR PROdUCTION (1949/2010)

\begin{tabular}{|c|c|c|c|c|c|c|c|c|}
\hline \multirow{2}{*}{ year } & \multicolumn{3}{|c|}{ planting area $\left(\right.$ million $\left.\mathrm{hm}^{2}\right)$} & \multicolumn{2}{c|}{ average yield (ton) } & \multicolumn{3}{c|}{ Sugar production (million ton) } \\
\cline { 2 - 9 } & cane & beet & total & cane & beet & \multicolumn{2}{c|}{ cane } & beet \\
\hline 1949 & 10.8 & 1.6 & 12.4 & 1.6 & 0.8 & 24 & 2 & 26 \\
\hline 2010 & 151.2 & 18.6 & 169.8 & 4.4 & 2.0 & 1013 & 60 & 1073 \\
\hline
\end{tabular}

Note: The data mainly came from Guangxi Sugar Network and China Sugar Association Annual Report.

There are 18 provinces which produce sugar, and the main sugar-producing region concentrated in the north, northwest and southwest of China. The sugar cane producing region are mainly distributed in Guangxi, Yunnan, Guangdong, Hainan and the neighboring provinces, and beet sugar are mainly distributed in Xinjiang, Heilongjiang, Inner Mongolia and some other neighboring provinces.

Before 1978, the period of planned economy, the sugar enterprises were owned by the state. Sugar production and sale were controlled by higher authorities and companies were not responsible for operation. The revenue of local governments has been mainly from sugar companies which had only profit owing to strict control by national plans for sugar prices during the period of started industry since 1978. Under this background, the number of Chinese local state-owned sugar industries developed rapidly, by 1991, there were more than 500 state-owned sugar enterprises, and sugar production reached 400 million tons. In 1991, the country liberalized price controls on sugar, and the system of commercial taxes was reformed in 1994. The way local government got revenue changed. Thus, the sugar industry lost "dual protection" from both the supply of raw materials and market demand, and the sugar industry began to enter the competition state. According to the traditional industry organization theory, market competition would lead to higher degree of market concentration, firm size would become larger and larger, and finally supermonopoly would appear, and government should make policies to limit the monopoly. How about Chinese sugar industry look like after 20 years of market competition?

The 20 years' development of China's sugar industry can be divided into two stages. The first stage is from 1991 to 2000 . The prominent feature of this stage is disorderly competition in the market.
The number sugar industries were more than 500 in the whole country, and sugar production capacity sprawled blindly because of a huge gap between supply and demand and local benefits. It is difficult for local government to solve these problems such as "hardly living big companies, nearly dying little companies", although the local government used many method such as contracting with the times, risk mortgage, and lease management. Sugar business kept looses and was insolvency year after year, and the problem of wage arrears for cane farmer and worker frequently occurred. The second stage is from 2000 till now. In 2000, government shutdown 150 sugar industries which were going bankrupt through pump priming for about 120 million, and propelled the reform of companies' property rights. Sugar industry entered into the period of stable development which bears the following fruits. First, from sugar planting, sugar production to using sugar as raw materials or materials a chain of food processing industry came into existence. Second, sugar cultivation and sugar production developed fast and China became the largest producer of sugar. Third, the capacity of comprehensive utilization was improved greatly, and many products such as paper, pulp board, fiberboard, yeast, citric acid, and alcohol was exploited with biogases and molasses as raw material (Table2). The rate of comprehensive utilization has reached $30 \%$. Fourth, the sugar industry improved concentration from 500 in 1991 to about 130 enterprise groups, subordinating about 280 sugar mills, and the scale of large enterprise groups increased. Fifth, the government improved its regulatory approach, and also accumulated a wealth of industry management experience. The central government regulated the price and controlled production planning, local government governed business operations before 1991. Although the 
central government did not restrict sugar, local government still intervened sugar cane buying and management of sugar factories driven by profit from 1991 to 2001. After 2000, sugar price was decided by both government and market with the reform of enterprise property rights. Government supervises the market order, promoting beneficial cooperation between sugar enterprises and farmers, and ensuring orderly sugar market competition.

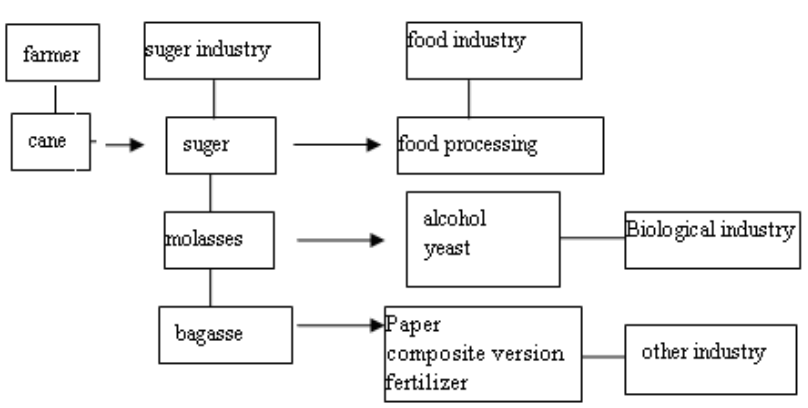

Figure1 Cane sugar industry china

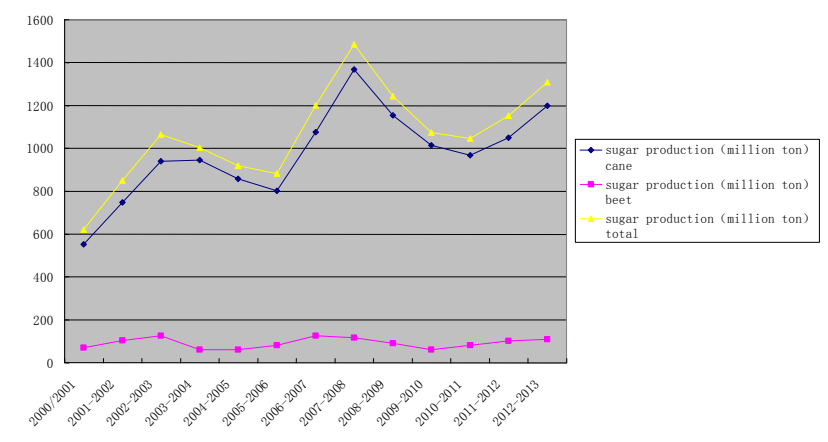

Figure2 Sugar production in china

The data in figure2 were sugar production in recent years. It can be seen Chinese sugar industry actually has advanced its scale through 20 years of market reform and competition. Then, how did it achieve the process of sugar industrial concentration? What are the conditions of the business scale expansion and the promotion market efficiency? Next, we'll carry out a case study by investigating Guangdong Hengfu Sugar Group Co., Ltd, which is one of top ten of China Sugar industry.

\section{EVOLUTION OF INDUSTRIAL ORGANIZATION- A CASE STUDY}

Hengfu Sugar Group is located in the southernmost tip of the Leizhou Peninsula in China. This region is in the zone of tropical marine monsoon climate, characterized by a frost-free all year, lots of showers in the hot season, and adequate heat, with an average annual temperature of $22.8-23.4^{\circ}$, the coldest average temp, in Jan being about $15^{\circ}$, and annual average sunshine hours being 1817.7-2160.8 hours. It is very suitable for sugarcane growth. This area has a long history of Sugarcane planting. Hengfu Sugar Group was a local state-owned sugar mill named Longmen sugar factory founded in 1958.Like other state-owned sugar factories, the problem of debt, poor management and shortage of raw materials for Longmen were also very serious. In 1999, Hengfu Company leased Longmen which was in the brink of bankruptcy. In 2002, Hengfu took over Longmen by bearing its debt. In the same year in December, it acquired state-owned Xiaqiao suger factory in the same region. In 2006, it took in the former state-owned Leicheng sugar mill, and in the same year Hengfu Sugar Group Corporation was established. After that, Hengfu took over many factories respectively, including the second sugar mill in Jianping County of Liaoning Province in 2007, Zhemeng and Manwan sugar mills in Jingdong County of Yunnan Province in 2008, Dahua Sugar Co. Ltd. and Ganhua Sugar Co. Ltd. in Leizhou Peninsula in 2009, and Dadi Sugar Co. Ltd. in Leizhou Peninsula and Guangdong Zhonggu Sugar Co. Ltd. in 2010. Untill now, Hengfu has 17 sugar mills, with the daily processing capacity of sugar of 64,100 tons, annual sugar out of 55 million tons, capacity of processing raw sugar of 50 million tons, annual alcohol output of 55,000 tons, taxes are more than 100 million yuan, total assets of Hengfu Group amounts up to 6.5 billion. It has grown into a enterprise with mass influence from a small company. The table 2 show the expansion process of Hengfu Group from 2002 till 2010.

TABLE II : HENGFU GROUP'S ABILITY OF PRODUCTION

\begin{tabular}{|l|c|c|c|c|c|c|c|c|c|}
\hline Sugarcan season & $01 / 02$ & $02 / 03$ & $03 / 04$ & $04 / 05$ & $05 / 06$ & $06 / 07$ & $07 / 08$ & $08 / 09$ & $09 / 10$ \\
\hline factory numbers & 1 & 2 & 2 & 2 & 3 & 4 & 5 & 9 & 17 \\
\hline $\begin{array}{l}\text { production per } \\
\text { day (million ton) }\end{array}$ & 1.2 & 1.6 & 1.6 & 1.6 & 2.0 & 2.2 & 2.4 & 4.0 & 6.4 \\
\hline
\end{tabular}

Hengfu Group has showed the following features in its course of growth:

\subsection{Integrating sugarcane manufacturing industry, extending it to planting}

China's sugar consumption was around 7.5 millions tons before 2000, but sugar production competence was about 7 million tons. For sugar manufacturing industry, having sugar material means owning market and benefit. However, taking the family as a unit, planting industry were confronted with the lack of capital and knowledge, laggard equipments, low sugar per unit yield and low rate of sugar content. The loss of sugar content after cutting was also great. Hengfu Group's precursor, Long Men 
sugar manufactory only bought 150 thousands tons sugarcane in 1999/2000, idling away over 200 million tons of production competence. After entering sugar industry, Hengfu Group made a deeply meticulous marketing research. Based on the analysis of Chinese market supply and demand situation and sugar industry operation rule, they thought that they need plenty of raw materials of high quality, to grasp opportunities of the market demand and reduce the average cost. Realizing that the most important element in sugar industry is abundant supply of sugarcane. They put forward the idea of "sugar farmer is the first manufacturing staff, and sugarcane farm is the first workshop of the corporation". They took the following measures to integrate sugarcane manufacturing industry into the industrial organization.

\subsubsection{Establishing material bases by making land classification and integration}

Firstly Hengfu Group contracted in some poor sloping fields, wasteland, and rural collective land. The Group invested money to make land leveling and plan, construct basic equipment of farm, and then contracted out back to and signed the sugarcane purchase- sale contract with farmers, who help planning and are willing to take order to produce sugarcane. Relatively good farmland that farmers operating and willing to take order to produce sugarcane, they help to planning.

According to the purchase-sale contract, they set the lowest price for the sugarcane and agreed that the farmers could share the benefit by $6 \%$ of sugar price when the sugar price is rising in the marketing. This kind of reciprocal and stable benefit predicted that Hengfu Group could own over 200 thousands ton of material in Leizhou Island in 2000 after entering sugar industry. This industrial integrated form was extended to a new productive area along with the Group Company's spread.

\subsubsection{Surrendering part of the profits to farmers, stabilizing material production}

In addition to the guarantee of purchasing price of the contract, the Group also provide free seedling to the farmers who make a large landscape planting, and pay capital beforehand for the farmers who are making a difficult living. Furthermore, the Group has implemented the standard that taking 20 Yuan from each ton of sugar as constructive capital of sugarcane area, for digging wells avoiding farm aridity. Farmers who are poor can run production without their own investment. It has greatly stimulated farmers' enthusiasm to plant sugarcane. The turnout of sugarcane has been firmly improved year by year. The Group gained 3.288 million tons of sugarcane, and produced 334 million tons of sugar in the season of 2009-2010.

\subsubsection{Producing scientifically, improving production level}

In order to increase the sugar per unit yield and the rate of sugar content, the Group established farm department, organized the farm technology service team consisting of experts in charge of training farmers with the agriculture technology and farm management. According to the production plan of sugar manufactory, the farm technology service team chose early, middle, and late good seeds, and scientific position inside the sugarcane area. Scientific farming could rises per unit of sugarcane yield from 2.5-3 tons to around 6 tons.

\subsubsection{Concretizing into community, improving the organization of sugarcane production}

The President of Hengfu Group was born and bred on Leizhou Peninsula, whose hometown is in sugarcane production area. He knows in rural China "acquaintances" "feelings," "trust" are very important for commercial operations. So they have actively got involved in the community life after entering sugar industry. Hengfu Group forwardly synchronized into the community life that the sugarcane production was located. The Company actively attended the community activities during every Chinese traditional festival. In the time of important festival, the Group not only donated a lot of money to the poor farmers who have no kin or cannot support themselves, but also pay for the local community activity expense according to the percentage of the sugarcane output, to support the village committee and the team of villagers to organize activities.

The core of Hengfu Group extending organization to Planting Industry is "firm + community + farmer". The traditional mode "firm + farmer", in which corporation signed the contract with farmers, farmers organized production independently, companies offer some requirement and direction, and then purchased the farmers' product according to the contract. During the actual operation process, the particularity of agricultural production leads to the result that both sides are taking opportunistic behaviors but cannot solve, conducting to the invalidation contract, marketing disorder, and cooperation risk increase. Hengfu Group realized that the Chinese characteristic "acquaintance society" shaped the social psychology focus on personal relationship. In rural area, village committee and the teams of villagers as the community managers play an important role in maintaining the society order of the rural area. Hengfu Group regarded village committee and the teams of villagers as a part of staff, brought into the Group, provided layout to them and organize them. Village committee and the teams of villagers' view that they are not only the third person who oversee the implement of contract between the Group and 
company, but also agency, who improves the relation between Group and farmers, communicate the requirement of both sides for the purpose of greatly improving the rate of contract implement.

\subsection{Scientific Management, Improving Corporations' Competitiveness}

The Corporations' Competence Theory believes that the root and basis of corporations' continuous competition relies on their core competence. The corporation's core competence is the holistic resource of corporation, coming down to the firm's technology, human resource, management, culture, cohesion, so on and so far. It has historic dependence, and is the result of corporation's unused study. Along with the enlarging scale of Hengfu Group CO., LTD., management level attaches more and more importance to internal management.

\subsubsection{Establishing quality and environmental management system, implementing scientific management}

Hengfu Group CO., LTD. really focuses on operation management, persistently consummates the production system of "elaborate manufacture, excelsior management". Its branch sugar manufactories all passed ISO9001:2000 Quality Management System Authentication, and acquired ISO14001:2004 Environmental Management System Certification. Its "Xue Xian" and "Jin Po" brand of White Granulated sugar are national inspection free products, national green products or famous products of GD province. The company gained "the China's Top Ten Brand Corporations with the biggest potential of development".

\subsubsection{Scientific evaluation, achieving scale firmly}

After 2000, China's sugar marketing gradually has regressed to rational order. Through 5 years preparation, Hengfu Group started to enter the enlarging scale period in 2006. Based on the scientific evaluation and enlarging risk, Hengfu Group is firmly enlarging with the mode of "firm + community + farmer". There are 13 manufactories in Leizhou Peninsula among the 17 brand manufactories of the Group. And some other conditions, including humanity custom and culture, and geographic advantage are available for the Group to manage internal corporation and sugarcane manufacture area and ensure their benefit.

\subsubsection{Innovating operation system, improving holistic benefit of production chain}

Sugar manufacturing industry connects with planting industry ahead, and link to food manufacturing after, simultaneously there is greatly wide development scale of exploiting byproducts of sugar manufacturing. The sugar manufacturing chain is long, and every industry in the chain closely connects with each other. It definitely decides a single corporation cannot control this chain, neither the risk of the whole chain. Therefore, when the economy scale reaches a stated level, people must implement according to their ability to try for the economy scale and innovate the new operation system. Only through this way can improve the holistic benefit of production chain. In term of profession, efficiency and operation experience, Hengfu Group formed the sugarcane production mode "firm + community + farmer" with the particularity that regard community as agency and give customer benefit as discount, independently use the automatically extending mode of production chain that honey produces alcohol and compound fertilizer "sugar + alcohol", that is the cycling economy exploitive mode using contracted form to shape the mode as "sugar manufacturing + deepprocessing byproduct". Through these modes operation, the sugar manufacturing industry gained a considerable economic and environmental benefit, improved the persistent development competence of sugar manufacturing industry.

\section{CONCLUSION}

Based on the background of Chinese sugar manufacturing, this paper surveyed the whole evolution process of industrial structure, pointed out that the evolution of modern industrial structure could not achieve the organizational system innovation without inducting particular elements to fit into the concrete situation in our country, and then improve industrial concentration, develop into scale economy so as to enlarge industrial chain and obtain scope economy.

The scarcity rate of resources decides whether the organizing boundary could be enlarging or shrinking. Organization has inner motivation to expansion to control scarce resources. The case Corporations extended the organizing boundary toward the sugarcane production when they made a choice at the edge of organizing boundary base on sugarcane scarcity in the sugar manufacturing. The control of sugarcane production was the key elements the decided whether the corporations could buy new firms or not.

Inducting particular local elements into the organization management could guarantee the validity of organization integration. Agricultural product processing industry is restricted by the biological characteristics of materials. In order to ensure the performing rate of contracts and keep resource of scarcity under control, the case 
corporations innovated the mode of "firm + community + farmer", enroll the community as agency, ensure the effectiveness of organizational resources integrated, and increase the performance rate of contracts when extending the organizing boundary toward the sugarcane production.

The scientific management of internal sciences of corporations. Economy scope must be choicely obtained base on the economy of scale. According to development stage, corporations could acquire the benefit of economy scope by choosing whether to independently control the complete production chain or some parts of it. The case corporations could gain the profit of economy scope at different levels by innovating the new operational mechanism, using the form of reciprocity, working independently or in cooperation.

In pursuit of economies of scale, enterprise organization must be based on its own core ability. And then it could achieve the purpose of increase production, reducing production cost. The case corporation's senior management personnel were born and bred in Leizhou Peninsula, and they added their knowledge about local culture and customs to the mode "firm + community + farmer", to increase its core capability. Its Competition strategy is keeping Leizhou Peninsula as the center with sugar manufacturing as the core business. It has been proved that the Competition strategy base on the core competitiveness has been very effective to Lower the transaction costs and increase production benefit.

\section{ACKNOWLEDGEMENT}

This article has got sustentation from Research base for the development on the scientific view in Guangdong.

\section{REFERENCES}

[1] Chandler, A. D., JrThe Visible Hand: The Managerial Revolution in American Business. Cambridge: Harvard University Press 1977.

[2] Don E. Waldman, Elizabeth J. JensenIndustrial organization: theory and practice 3rd Edition. China Machine Press2009.

[3] Li xinqin, li shiming, lan yong Research on the structure and types about Industrial chain Journal of University of electronic science and technology, pp.1-64, spr2004.

[4] Min dan, han liyan(2008) Market structure, Industry cycle and Capital structure-based on Strategic company financial theory Managed world, China. pp. 81-89, Feb2008.

[5] Mulla Nathan, David ScharfsteinDo firm boundaries mater? American Economic Review, Vol91, pp, 195-199, Feb2001.

[6] Wang ya xin case study of the local state-owned enterprise system development Journal of zhanjiang normal college, China. pp. 92-95, Feb2005.

[7] Wang yunxia, li guoping (2006) Review on Research in industry chain Industrial technology economy, China. pp, 61-65, Oct2006.

[8] Williamson Oliver E. The modern corporation: origins, evolution, attributes Journal of Economic Literature, Vol19, pp. 1537-1568, Spr1981.

[9] Zhang lixiang Industrial organization, Industrial chain integration and Industry sustainable development Managed world, China. pp. 78-87, Spr2007. 